\title{
A CASE STUDY ON THE ADVANTAGES OF USING ELECTRONIC-BASED ASSESSMENT FOR AN ACADEMIC COURSE IN PUBLIC UNIVERSITY
}

\author{
Choon Keong, Tan ${ }^{1}$ \\ Faculty of Psychology \& Education, \\ Universiti Malaysia Sabah (UMS) \\ (Email: cktanums@gmail.com) \\ Nguyen Bich Dieu ${ }^{2}$ \\ Faculty of Psychology \& Education, \\ Universiti Malaysia Sabah (UMS) \\ (Email: bichdieunguyen@gmail.com) \\ Hwa Choo, Kang ${ }^{3}$ \\ Teacher Training Institute, \\ Kent Campus, Malaysia \\ (Email: hwachookang210@gmail.com)
}

Accepted date: 16-03-2019

Published date: 17-07-2019

To cite this document: Tan, C. K., Nguyen, B. D., \& Kang, H. C. (2019). A Case Study on the Advantages of Using Electronic-Based Assessment for An Academic Course in Public University. International Journal of Modern Education, 1(1), 17-27.

DOI: $10.35631 /$ ijmoe. 11002

\begin{abstract}
The examination had been carried out traditionally in exam halls for the past decades for academic courses evaluation. Would electronic-based exam via the computers be the preferred mode in years to come? With the advancement of computer communications technology and application software development, this online option will become popular for achievement assessment in the near future. This study involved 86 undergraduates who took a computer in education course at the Faculty of Psychology and Education of the public university in Sabah, East Malaysia. It examined the experiences of the students in taking an electronic-based exam during the course. The administration of the electronic-based exam was done using prototype exam software created by the main author. They were also asked to compare their experiences that they had accumulated with the traditional paper-based exam. The study revealed that the electronic-based exam was better than traditional paper-based exam in areas related to perceptions (enjoyment, fun, etc.), exam management strategies and cost-saving. Although traditional paper-based exams are still being practiced extensively worldwide in institutions of higher learning due to its good exam security, it is undeniable that electronic-based exam had also created some positive impacts especially in the administration of exam results and other related records.
\end{abstract}

Keywords: Assessment, Evaluation, Electronic-Based Exam 


\section{Introduction}

Many universities and colleges, particularly public institutions in Malaysia, enrolled a high number of undergraduates for various degree programmes in the last 10 years. Lecturers are constrained with lots of workloads especially in manually marking exam papers. Can some exams be multiple-choice-based (MCQ) in increase its objectivity? Evaluation is part and parcel of educating. Assessment is an important element in the teaching and learning process that challenges instructors to consider evaluation techniques that meet the learning needs of today's adult learners (Zimmerman and Schunk, 2011). This study explores the possibility of using electronic-based exam as a supplementary approach to the heavy use of subjective assessment of essay writing for expressing ideas.

\section{Aim of the Study}

The main objectives of the study are to investigate the perceptions of students using electronic-based exam and issues related to management of exams using the online and traditional method. In detail, the research questions are as follow:

1. Is electronic-based exam perceived to be better than traditional paper-based exam?

2. What are the perceived advantageous of electronic-based exam?

3. Is electronic-based exam more effective in term of exam management compared to traditional paper-based exam?

\section{Literature Review}

Integrating evaluation with program development is critical to producing educational programs that have demonstrable impact. The most important purpose of evaluation is not to prove but to improve. It is important to look at evaluation using the meta-cognition approach (Negretti, 2012). Most teaching and learning needs formative assessment to be an integral part to check program development process of students. Dinsmore and Parkinson (2011) stressed that formative assessment provides feedbacks on the program implementation via exercises and exams for each module. Lecturers will know the effectiveness of their teachings if formative assessments are done with students.

The basic theory of evaluation started as the Formative-Summative approach that is a contrast to Stufflebeam's CIPP model and Stake's Countenance approach (Zimmerman \& Schunk, 2011). He defined evaluation as engaging an assessor to judge the performance based on objects or accumulated evidences of learning.

Formative assessments can be done via portfolio and reflections by students (Sanders, 2001; Dinsmore \& Parkinson, 2011). Recent advance in ICT technology has enabled more companies to come up with MCQ option for fast marking and results (Touchie, 2012). The biggest advantage of MCQ method is its ability to incorporate problem-based questions into the assessments. The skills test required by science and engineering discipline can be in MCQ format and its popularities have increased rapidly (Zimmaro, 2010).

Assessment and evaluation in an online environment need to be approached differently than traditional classroom assessment. In classrooms, heavy emphasis is often placed on tests and essays as a means of determining student learning. Online, alternative forms of assessment are often more effective. Group presentations, reflective journals, projects, simulations, etc. allow students flexibility in expressing their learning and exercise their higher order thinking skills (Dinsmore \& Parkinson, 2011). Beyond being a more effective gauge of learning, alternative assessment techniques also discourage cheating and plagiarism. Authentic assessment requires a student to demonstrate understanding. The focus of evaluation and 
assessment online is to ensure that learning has occurred. If the method of assessment is such that it obstructs effective evaluation of learning, different approaches need to be considered.

Assessment is an important element in the teaching and learning process that challenges instructors to consider evaluation techniques that meet the learning needs of today's adult learners (Wiliam, 2011). The teacher's assessment strategies are significant because they provide a relational prompt for students and insights into the educational process. Evaluating the teaching and learning process involves a host of activities such as creating course objectives, gathering data from a variety of sources and often assigning grades for student work. Hopefully, relevant assessment methodology should accurately inform both the teacher and student about the quality of the learning experiences.

The process of assessment involves gathering information from a variety of sources to cultivate a rich and meaningful understanding of student learning. A primary aim of assessment is providing the necessary information to improve future educational experiences (Tomlinson, 2013). Yet, it is vital that the assessment data be accurate and relevant to effectively make informed decisions about the curriculum. It requires taking the time to ask relevant questions that help evaluate the effectiveness of the teaching strategies and curriculum plans (Huba \& Freed 2000).

Zimmerman and Schunk (2011) relate that an important purpose of evaluation is to determine if all of the learners developed important knowledge, skills, and attitudes as a result of the program. This highlights that the evaluation of adult learning has a variety of instructional purposes and impacts various stakeholders who are interested in the educational process. Appropriate assessment instruments can offer valuable information to teachers, students and administrators. According to Wiliam (2011), ultimately evaluation is important to the educational process because it provides feedback on whether the course and learning objectives have been achieved to satisfactory level.

A relevant approach to assessing adult learners supports a student-centered educational philosophy. The focus involves helping individuals become more self-directed in their learning plans and activities. This is a situational goal that requires assessment procedures that acknowledges their needs, gifts and talents (Tomlinson, 2014). Teachers must recognize that adults are autonomous learners who have varying degrees of independence in their study habits and desire relevance in the evaluation of their assignments (Zimmerman \& Schunk, 2011).

The student-centered model of learning encourages teachers to view their students as academic partners who work together to produce relevant and meaningful learning experiences (Liebers, 1999). It requires professors who are willing to change their standard teaching methods. Assessment procedures need to foster a meaningful bridge between academic knowledge, skills and experiences of the classroom to the student's daily job. Teachers are challenged to create evaluations that reflect respect for adult learners' experiences while promoting growth (Collison et al., 2000).

Electronic-based exams are now more readily available as most students are virtually connected via internet. The use of electronic-based exams will facilitate faster results and more accuracy especially in MCQ-based questions (David et al., 2013). Multiple choice test items are less susceptible to guessing than true/false questions, making them a more reliable means of assessment. The reliability is enhanced when the number of MC items focused on a 
single learning objective is increased (Brame, 2013; Zimmaro, 2010). Rahul (2017) also stated that easily editable answers to electronic-based exams will see this option more popular in the near future. This study will prove that electronic-based exams can be applied successfully in university.

The Theoretical Framework of This Study is Shown in Diagram 1.

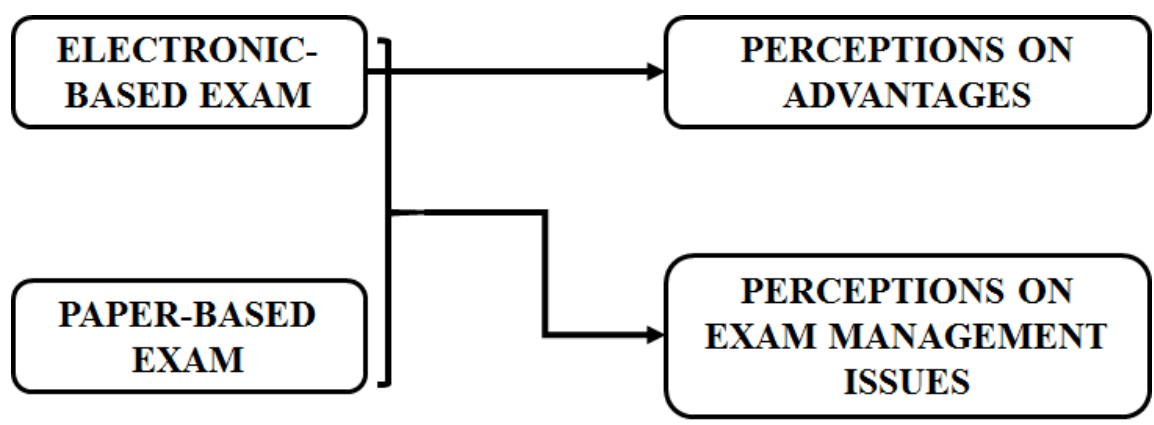

Diagram 1: Theoretical Framework

\section{Method, Sampling and Instruments}

This research was based on a case study of a group of university students in Sabah, Malaysia. The survey approach was used. It was done on 86 undergraduates undergoing a computer course in the Faculty of Psychology and Education. The subjects took an electronic-based exam using a prototype electronic-based exam system created by the main author. The system will administer the exam on the students in batches or sessions.

A screen shot of the main menu of the prototype electronic-based exam system is shown in Diagram 2.

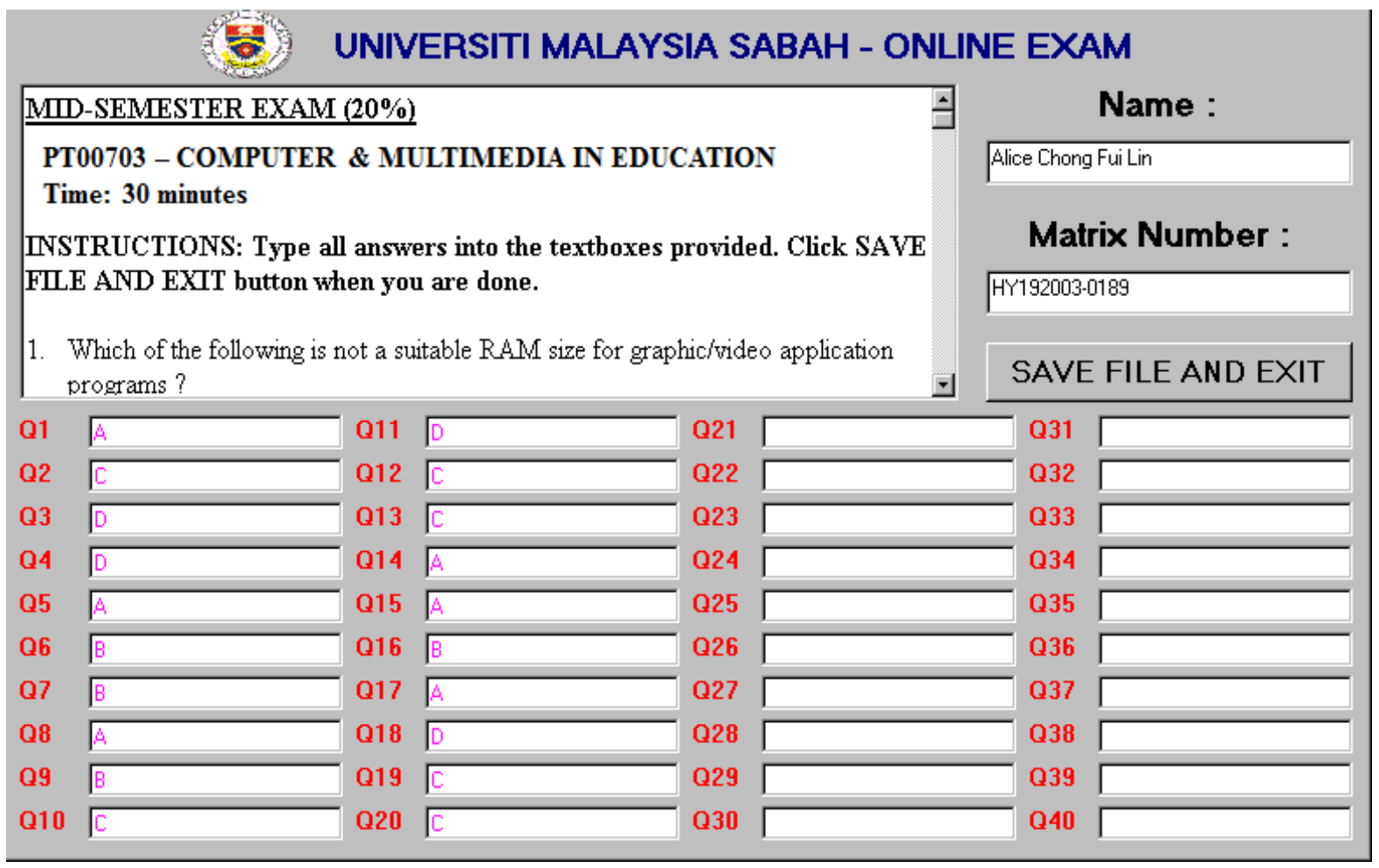

Diagram 2: Screen Shot of The Main Menu of The Electronic-Based Exam for A Computer Course 
Students can scroll the exam questions easily using the scroll bar on the right-hand side of the textbox that displays the questions. Answers that are entered into the textboxes are also editable easily. This feature is better than paper-based exam where editing answers can be a real problem when erasers are not provided and moreover, rubbing and rewriting the answers again is very time consuming.

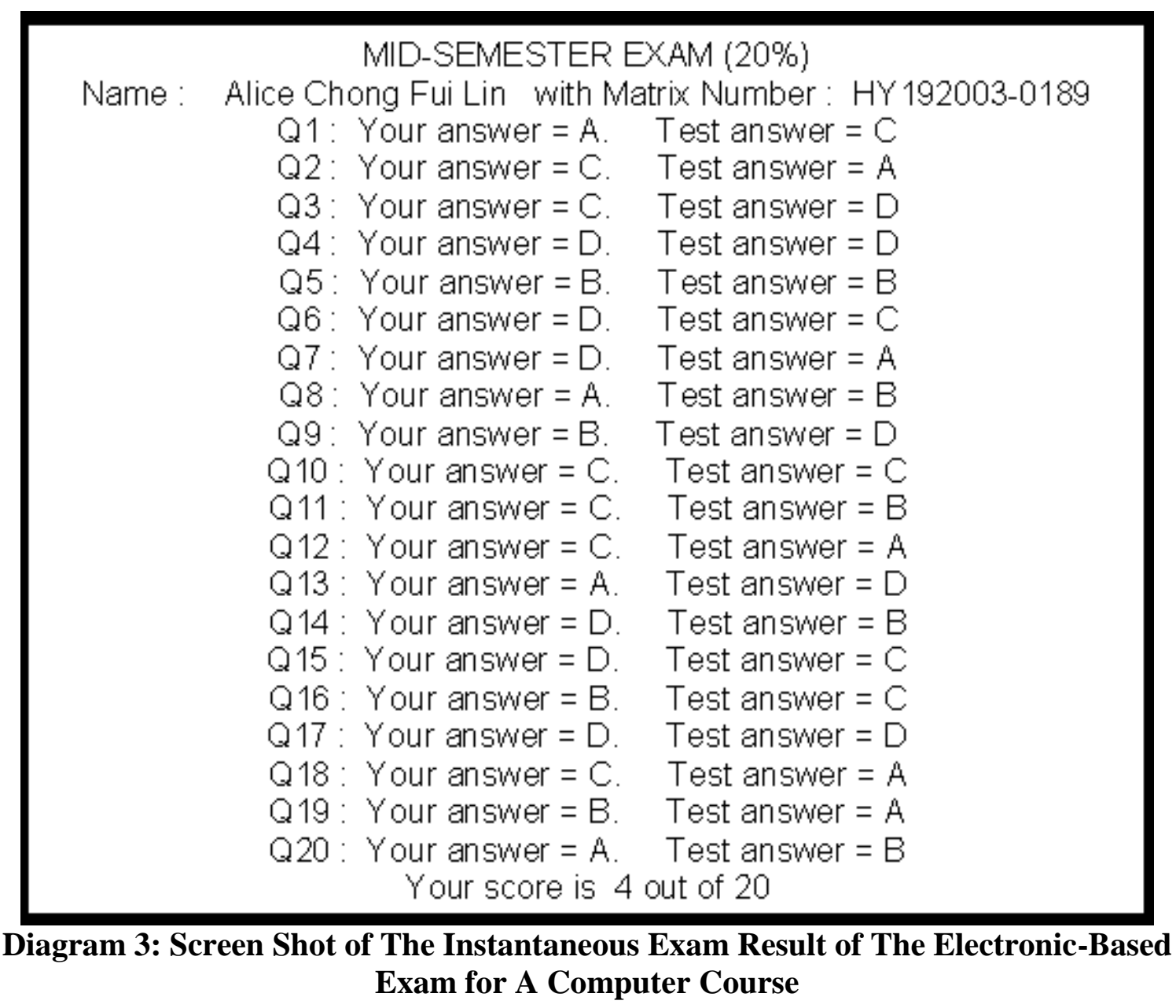

When the student has completed answering the questions, they will click the "Save and Exit" button. Exam result is instantly known and automatically saved into a text file. Diagram 3 above shows the result of a candidate after she had submitted the answers.

After taking the exam, a 24-item questionnaire on the respondents' perception towards taking electronic-based exam was given to them. The split-half reliability of the construct yielded a $r$ value of 0.70 . The questionnaire asked respondents' perception on the administrative part of the electronic-based exam they took, their enjoyment and the ease-of-use features of the system.

Another 18 -item questionnaire with a split-half reliability of $r=0.74$ was also administered to gauge respondents' perception on traditional paper-based exam. The purpose of the questionnaire was to survey their perception related to the stress, enjoyment and effectiveness of exam administration. 
Both questionnaires were constructed based on examples illustrated in the "Handbook of Practical Program Evaluation" by Kathryn et al. (2015). The questionnaires were checked and certified by an evaluation program lecturer from the university. Both questionnaires rated the respondents' perception on a 5-point Likert Scale. A score of 5 is the maximum. A positive perception is defined as a mean score of 3.0 and above. The data from both questionnaires were keyed into SPSS statistical software to get the mean and standard deviation values for descriptive statistical analyses.

\section{Results and Discussion}

Table 1 shows the result of the questionnaire survey on respondents' perception towards taking electronic-based exam as compared to taking traditional paper-based exam. The mean score and the standard deviation were 3.74 and 1.1900 respectively. $74.4 \%$ of the respondents agreed that taking electronic-based exam in the lab is better than having traditional paperbased exam in the hall. Most of them felt that electronic exam was better because the exam software has good distinctive feature such as answers can be edited easily, air-conditioned lab and paperless environment. David et al. (2013) stated that online exam had more flexibilities compared to traditional paper-based exam.

Table 1: Mean, SD and Percentage of The Respondents' Perception Towards Taking Electronic-Based Exam as Compared to Taking Traditional Paper-Based Exam

\begin{tabular}{|c|c|c|c|}
\hline $\begin{array}{l}\text { Perception towards taking electronic- } \\
\text { based exam as compared to taking } \\
\text { traditional paper-based exam }\end{array}$ & Mean & $\begin{array}{l}\text { Standar } \\
\text { d } \\
\text { Deviatio }\end{array}$ & $\begin{array}{l}\text { Percentage of "Agree" } \\
\text { \& "Strongly Agree" } \\
(\mathbf{n}=\mathbf{8 6})\end{array}$ \\
\hline
\end{tabular}

\begin{tabular}{llll}
\hline ITEM 12: Taking electronic-based exam & 3.74 & 1.1900 & 74.4 \\
in the lab is better than having traditional & & & \\
paper-based exam in the hall & & & \\
\hline
\end{tabular}

On respondents' feelings using computers for electronic-based exam, three important items were asked (Table 2). Out of 86 respondents, 90.7\% (mean score $=4.23, S D=0.9033$ ) of them stated that electronic-based exam is very much a new experience for him/her. This proved that it was a rare opportunity for them to use this mode of exam.

Table 2: Mean, SD and Percentage of The Respondents' Feelings Using Computers for Electronic-Based Exam

\begin{tabular}{lccc}
\hline \multicolumn{1}{c}{$\begin{array}{c}\text { Feelings using computers for } \\
\text { electronic-based exam }\end{array}$} & Mean & $\begin{array}{c}\text { Standard } \\
\text { Deviation }\end{array}$ & $\begin{array}{c}\text { Percentage of } \\
\text { "Agree" \& } \\
\text { "Strongly Agre" } \\
\text { (n= 86) }\end{array}$ \\
\hline $\begin{array}{l}\text { ITEM 1: Electronic-based exam is } \\
\text { very much a new experience for me }\end{array}$ & 4.23 & 0.9033 & 90.7 \\
$\begin{array}{l}\text { ITEM 2: Electronic-based exam is } \\
\text { fun and enjoyable }\end{array}$ & 3.74 & 0.9963 & 73.3 \\
$\begin{array}{l}\text { ITEM 3: I feel relaxed while } \\
\text { answering the questions }\end{array}$ & 3.31 & 1.0089 & 52.3 \\
\hline
\end{tabular}

About $73.3 \%$ of the respondents (mean score $=3.74, S D=0.9963$ ) felt that electronic-based exam is fun and enjoyable. This was caused by of the great ease of editing exam answers inputted by the students and the one click 'Save and Exit' feature. Most undergraduates like electronic-based exam because they had some previous computer literacy experience in 
schools. As illustrated by David et al. (2013) modern electronic-based exams also need to be improved to include multimedia elements such as graphics to make assessment fun.

Out of 86 respondents, only $52.3 \%$ (mean score $=3.31, S D=1.0089$ ) of them felt relaxed while answering the exam questions. Electronic-based exam might be fun, but it generated a lot of unnecessary pressure because it was an exam that carried some marks for the course they take. Therefore, it was not surprising to find that only about half of the respondents felt relaxed in this electronic-based exam.

Table 3: Mean, SD and Percentage of The Respondents' Perception Towards Using Interfaces While Taking Electronic-Based Exam

\begin{tabular}{lccc}
\hline \multicolumn{1}{|c}{$\begin{array}{l}\text { Perception towards using interfaces } \\
\text { while taking electronic-based exam }\end{array}$} & Mean & $\begin{array}{c}\text { Standar } \\
\mathbf{d} \\
\text { Deviatio } \\
\mathbf{n}\end{array}$ & $\begin{array}{c}\text { Percentage of } \\
\text { "Agree" \& "Strongly } \\
\text { Agree" } \\
\text { (n= 86) }\end{array}$ \\
\hline $\begin{array}{l}\text { ITEM 3: I can edit the typed answers } \\
\text { easily }\end{array}$ & 4.05 & 0.9192 & 82.6 \\
$\begin{array}{l}\text { ITEM 4: The exam questions can be read } \\
\text { easily by scrolling the scroll bar }\end{array}$ & 4.37 & 0.5324 & 97.7 \\
$\begin{array}{l}\text { ITEM 6: I can get my exam result } \\
\text { instantly }\end{array}$ & 4.38 & 0.5974 & 96.5 \\
$\begin{array}{l}\text { ITEM 7: Instructions on sending exam } \\
\text { script are clear }\end{array}$ & 4.20 & 0.9181 & 90.7 \\
$\begin{array}{l}\text { ITEM 11: Textboxes are provided for me } \\
\text { to key in my answers }\end{array}$ & 4.40 & 0.5796 & 97.7 \\
\hline
\end{tabular}

Table 3 shows the perception of the respondents towards using interfaces while taking electronic-based exam. Some $82.6 \%$ of them (mean score $=4.05, S D=0.9192$ ) felt that editing answers that were already typed into the textboxes was easy. This was due to the editable feature of the textboxes content that was programmed by the researcher. About $97.7 \%$ of them (mean score $=4.37, S D=0.5324$ ) said that it was easy to read exam questions via the provided scroll bar. This made higher accessibility to the exam questions and contributed to the positive feelings of the respondents for having this type of exam (David et al., 2013).

Out of 86 respondents, $96.5 \%$ (mean score $=4.38, S D=0.5974$ ) of them stated that they could get their result instantly. This was true as shown in Diagram 2 earlier that the exam result was saved instantly into a text files when they clicked 'Save and Exit' button. Some $90.7 \%$ of the respondents (mean score $=4.20, S D=0.9181$ ) said that instructions on sending exam script are clear. The instructions were printed on top of the exam script. The purpose was to make electronic-based exam easier to use and the users properly guided.

About $97.7 \%$ of them (mean score $=4.40, S D=0.5796$ ) said that textboxes are provided for $\mathrm{him} / \mathrm{her}$ to key in exam answers. These interfaces (the textboxes) served as inputs to the exam evaluation system so that comparisons with the script answers could be made by the assessment function of the exam system. The advantage of having the textboxes was to make editing of answers by the users easy (Zimmaro, 2010). 
Table 4: Mean, SD and Percentage of The Respondents' Perception Towards Administration of Electronic-Based Exam

\begin{tabular}{lccc}
\hline $\begin{array}{c}\text { Perception towards administration of } \\
\text { electronic-based exam }\end{array}$ & Mean & $\begin{array}{c}\text { Standard } \\
\text { Deviation }\end{array}$ & $\begin{array}{c}\text { Percentage of } \\
\text { "Agree" \& "Strongly } \\
\text { Agree" } \\
\text { (n= 86) }\end{array}$ \\
\hline $\begin{array}{l}\text { ITEM 8: Electronic-based exam can save } \\
\text { a lot of paper printing cost }\end{array}$ & 4.59 & 0.6208 & 98.8 \\
$\begin{array}{l}\text { ITEM 9: Electronic-based exam needs to } \\
\text { be organized into many sessions }\end{array}$ & 4.08 & 0.7703 & 83.7 \\
$\begin{array}{l}\text { ITEM 10: Administration of exam result } \\
\text { is easier using electronic-based exam }\end{array}$ & 4.17 & 0.7226 & 89.5 \\
\hline
\end{tabular}

On the administration of the electronic-based exam, $98.8 \%$ of the respondents (mean score $=$ $4.59, S D=0.6208$ ) felt that it saves a lot of paper printing cost. This was indeed quite true because the world's forest is depleting at a fast rate at the expense of producing paper or wood-based products. On top of that, printing exam scripts needs other expenses as well such as cost of ink, time and labour. Therefore, it is good to have electronic-based exam because it helps to reduce the use of paper. This is also supported by David et al. (2013).

One problem for electronic-based exam most probably was the need to organize it into many smaller sessions. About $83.7 \%$ of them felt so (mean score $=4.08, S D=0.7703$ ). This move was inevitable because of limited technical resources such as computer labs and computers. But administrating each of the smaller session was very much easier compared to administering a big number of exam candidates in a hall. In addition, $89.5 \%$ of the respondents (mean score $=4.17, S D=0.7226$ ) agreed that administrating electronic-based exam was very much easier. This was true because the system was designed to assess candidates' answers automatically. It is more efficient than manual processing in the case of traditional paper-based exam.

Table 5 shows the respondents' feelings towards taking traditional paper-based exam. About $60.5 \%$ of the respondents (mean score $=3.37, S D=1.1687$ ) felt that taking exam in an examination hall is very stressful for him/her while $57.0 \%$ of them (mean score $=3.29, S D=$ 1.1047) thought that they felt tense when answering questions in an examination hall. This was particularly true if you face uncomfortable environment of the exam hall with the sight of everybody's stressful and pressurized look. If the exam is not air-conditioned, the stress level of the exam candidates may even increase (Rahul, 2017). Such was the recalled experience of the respondents when traditional paper-based exam was conducted on them for many of the public exams that they had undergone.

Only $47.7 \%$ of the respondents (mean score $=3.24, S D=1.0509$ ) enjoyed having exam in the examination hall. With electronic-based exam providing the other option for exam, it was not surprising that only slightly less than half of them thought so. Traditional paper-based exam was already well known by the respondents to be quite stressful and uncomfortable as compared to the mini sophisticated lab that served the electronic exam option. 
Table 5: Mean, SD and Percentage of The Respondents' Feelings Towards Taking

Traditional Paper-Based Exam

\begin{tabular}{lccc}
\hline $\begin{array}{c}\text { Feelings towards taking traditional } \\
\text { paper-based exam }\end{array}$ & Mean & $\begin{array}{c}\text { Standard } \\
\text { Deviation }\end{array}$ & $\begin{array}{c}\text { Percentage of } \\
\text { "Agree" \& "Strongly } \\
\text { Agree" } \\
\text { (n= 86) }\end{array}$ \\
\hline $\begin{array}{l}\text { ITEM 1: Taking exam in an examination } \\
\text { hall is very stressful for me }\end{array}$ & 3.37 & 1.1687 & 60.5 \\
$\begin{array}{l}\text { ITEM 2: I feel tense when answering } \\
\text { questions in an examination hall }\end{array}$ & 3.29 & 1.1047 & 57.0 \\
$\begin{array}{l}\text { ITEM 5: I enjoy having exam in the } \\
\text { examination hall }\end{array}$ & 3.24 & 1.0509 & 47.7 \\
\hline
\end{tabular}

The respondents' perception towards editing answers while taking traditional paper-based exam is shown in Table 6. Some $77.9 \%$ of the respondents (mean score $=3.87, S D=1.0381$ ) found that editing answers is not so easy because they need to be erased the answer first. Editing a written answer especially a sentence is quite time consuming and there is no guarantee that it can be done neatly. A lot of examiners are very fussy about tidiness of written exam scripts and some may even consider deducting marks for untidy product. This is where electronic-based exam has the edge because editing answers is easy and consumes less time. On top of that, answers can be changed many times without a single trace of previous answers on the printed final copy of the answers.

Table 6: Mean, SD and Percentage of The Respondents' Perception Towards Editing Answers While Taking Traditional Paper-Based Exam

\begin{tabular}{lccc}
\hline $\begin{array}{c}\text { Perception towards editing answers } \\
\text { while taking traditional paper-based } \\
\text { exam }\end{array}$ & Mean & $\begin{array}{c}\text { Standard } \\
\text { Deviation }\end{array}$ & $\begin{array}{c}\text { Percentage of } \\
\text { "Agree" \& "Strongly } \\
\text { Agree" } \\
\text { (n= 86) }\end{array}$ \\
\hline $\begin{array}{l}\text { ITEM 3: Editing answers is not so easy } \\
\text { because they need to be erased first }\end{array}$ & 3.87 & 1.0381 & 77.9 \\
\hline
\end{tabular}

In term of exam management, $93.0 \%$ of the respondents (mean score $=4.42, S D=0.7270$ ) agreed that a considerate amount of money is spent on printing exam papers (Table 7). This reconfirmed earlier finding where $98.8 \%$ of the respondents (mean score $=4.59, S D=$ 0.6208) felt that it saves a lot of paper printing cost for electronic-based exam. Therefore, to save the forest and paper cost, we should opt for electronic-based exam in the future (Rahul, 2017).

Table 7: Mean, SD and Percentage of The Respondents' Perception Towards Administration of Traditional Paper-Based Exam

\begin{tabular}{lccc}
\hline $\begin{array}{c}\text { Perception towards administration of } \\
\text { traditional paper-based exam }\end{array}$ & Mean & $\begin{array}{c}\text { Standard } \\
\text { Deviation }\end{array}$ & $\begin{array}{c}\text { Percentage of } \\
\text { "Agree" \& "Strongly } \\
\text { Agree" } \\
\text { (n= 86) }\end{array}$ \\
\hline $\begin{array}{l}\text { ITEM 4: A considerate amount of money } \\
\text { is spent on printing exam papers }\end{array}$ & 4.42 & 0.7270 & 93.0 \\
$\begin{array}{l}\text { ITEM 6: The advantage of having exam in } \\
\text { a hall is that a single exam session can be }\end{array}$ & 4.12 & 0.7099 & 89.5 \\
\end{tabular}


held

ITEM 7: I need to wait for my exam result

for a duration of time fixed by the lecturer

ITEM 8: Conducting exam in the hall has

4.40

0.6908

95.3

less problem compared to electronic-

$3.20 \quad 1.1253$

46.5

based exam

ITEM 9: Collecting exam scripts after an

4.26

0.7060

95.3

exam takes quite some time

Some $89.5 \%$ of the respondents (mean score $=4.12, S D=0.7099$ ) stated that the advantage of having exam in a hall is that a single exam session can be held. This was particularly true for exam with a big number of candidates. It would not be viable to hold too many lab sessions for electronic-based exam whereas hall may be the likely solution. However, it is wise to note that although it has to be conducted in many sessions, the distinct advantage is still the automated assessment and evaluation of the exam result. It saves labour and other related processing cost.

About $46.5 \%$ of them (mean score $=3.20, S D=1.1253$ ) agreed that conducting exam in the hall has less problem compared to electronic-based exam while $95.3 \%$ of them (mean score $=$ $4.26, S D=0.7060$ ) found that collecting exam scripts after an exam takes quite some time. This demonstrated that although conducting exam in a hall has some advantages such as single session, but much time is needed for collecting exam scripts really nowhere better compared to electronic-based exam where a single click of button mark the collection of the script, its mark and other related parameters that are processed.

The long processing time needed by the course lecturer to deliver the exam result is also discouraging. This was agreed by $95.3 \%$ of the respondents (mean score $=4.40, S D=$ 0.6908). Unlike traditional paper-based exam, exam result is instantaneous in electronicbased exam (Rahul, 2017). By weighing the pros and cons of traditional paper-based exam, the electronic-based option seems to have a slight edge because it saves paper-printing cost and has automated evaluation system.

\section{Recommendations and Summary}

The findings showed that electronic-based exam is well accepted by the subjects of this study. Most electronic-based exam systems function as automated systems that produce quick results and save time (Rahul, 2017). It is important to note that electronic-based exam generates results immediately and it is always possible for the examiner and students to get information on his results instantly. It becomes more and more popular in many universities and colleges where online exam via the internet is a possible option. This option is not being restricted by geographical locations and is fair and reasonable. When electronic-based exam is practiced in schools, it can reduce the marking workload of teachers and also ensures objectivity and fairness to the schools (David et al., 2013). Therefore, the authors recommend that more universities will use electronic-based as part of the assessment for academic courses to reduce the workloads of university lecturers.

\section{References}

Brame, C. (2013). Writing good multiple-choice test questions. Retrieved from https://cft.vanderbilt.edu/guides-sub-pages/writing-good-multiple-choice-testquestions/ 
Collison, G. Elbaum, B., Haavind, S., \& Tinker, R. (2000). Facilitating online learning: Effective strategies for moderators. Madison, WI: Atwood Publishing.

David F., Mark R. \& Lu Yin (2013). Is It Live or Is It Internet? Experimental Estimates of the Effects of Online Instruction on Student Learning. Journal of Labor Economics, 31(4).

Dinsmore, D. L., \& Parkinson, M. M. (2011). What are Confidence Judgments Made of? Students' Explanations for their Confidence Ratings and What that Means for Calibration. Paper presented at the annual meeting of the American Educational Research Association, New Orleans.

Huba, M. E. \& Freed, J. E. (2000). Learner-centered assessment on college campuses: Shifting the focus from teaching to learning. Boston, MA: Allyn \& Bacon.

Kathryn E. N., Harry P. H \& Joseph S. W. (2015). Handbook of Practical Program Evaluation (4 $4^{\text {th }}$ Ed.). New Jersey: Wiley. doi: 10.1002/9781119171386

Liebers, C. S., (1999). Journals and portfolios: Alternative assessment for preservice teachers. Teaching Children Mathematics, 6 (3), 164-169.

Negretti, R. (2012). Metacognition in student academic writing: A longitudinal study of metacognitive awareness and its relation to task perception and evaluation of performance. Written Communication, 29(2), 142-179. doi: $10.1177 / 0741088312438529$

Rahul Shahane, Shubham Bobde, Suraj Chaudhari \& Jagupati Golguri (2017). Web Based Online Examination System, Global Research and Development Journal for Engineering, 2 (5).

Sanders, L. R. (2001). Improving assessment in university classrooms. College Teaching, 49 (2), 62-64.

Tomlinson, C., \& Moon, T. (2013). Assessment and student success in a differentiated classroom. Alexandria, VA: ASCD

Tomlinson, C. (2014). The differentiated classroom: Responding to the needs of all learners (2nd ed.). Alexandria, VA: ASCD

Touchie, C. (2012). The development of multiple-choice questions using the key-features approach. Retrieved from Medical Council of Canada Web site: http://www.mcc.ca/en/news/Faculty_visits/McGill.shtml

Wiliam, D. (2011). Embedded formative assessment. Bloomington, IN: Solution Tree

Zimmaro, D. M. (2010). Writing good multiple-choice exams. Retrieved from University of Texas at Austin, Center for Teaching and Learning. Retrieved from http://ctl.utexas.edu/assets/Evaluation--Assessment/Writing-Good-MultipleChoiceExams-04-28-10.pdf

Zimmerman, B. J., \& Schunk, D. H. (2011). Handbook of Self-Regulation of Learning and Performance. NewYork, NK: Routledge. 